\title{
The Effect of Inequality of Educational Facilities, Health, and Road Conditions toward Income Distribution in Central Java Province, Indonesia
}

\author{
Antono Herry ${ }^{1}$, Purnomo Adhi ${ }^{2}$, Firmansyah $^{3}$ \\ ${ }^{1}$ Departement of Economics, Universitas Diponegoro, Indonesia \\ ${ }^{2}$ Department of Economic Education, Universitas PGRI Semarang, Indonesia \\ ${ }^{3}$ Department of Economics, Universitas Diponegoro, Indonesia
}

\begin{abstract}
This study examines the effect of inequality of public facilities, namely education, health, and road condition, on the income inequality in Central Java Province, Indonesia. By employing the time-series data of 15 years, this study analyzes the Gini index and the relationship between the Gini index and Index of public facilities by the regression model. The study finds that the inequality of the provision of public facilities affects the income distribution in Central Java, Indonesia
\end{abstract}

Keywords: inequality, income distribution, gini index

\section{Introduction}

Development is a fundamental process of changing the aspects of people's lives. Development should be understood as a multi-dimensional process involving major changes in social structure, community attitudes, and national institutions, such as accelerating economic growth, reducing inequality, and eradicating absolute poverty[1]. Thus, development should lead to better living conditions for people. Development outcomes should contribute to improving the welfare of the people. Therefore, development should pay attention to the principles of good development in developing countries and in developed countries, which focuses on all assets: physical capital, human, and natural, complete distributive aspects over time, and emphasizes the institutional framework for governance good[2].

Gaps availability of public facilities is also a challenge for the region. The availability of public facilities also has an agglomerated tendency in certain areas that are considered to have a strategic position in the economic field. The gap in the provision of public facilities could have an impact on the smoothness of the regional development process. Availability of public facilities will stimulate the interest of private parties to invest.

In line with that idea, this study attempts to examine the effect of the gap in public facilities provision on income inequalities. The provision of public facilities in several regencies/cities in Central Java, is expected to affect the distribution of income between regencies/cities. The gap will be analyzed using Gini index. This study aims to identify the effect of the gap education facilities, health, and road conditions on income distribution in Central Java Province. Some of the research problem is formulated as follows: (1) are there gaps the educational facilities influence on the income distribution gap?; (2) are there gaps the health facility influence on the income distribution gap?; and (3) is there any influence of the existence of the damaged road condition on the income distribution gap?

Regional desentralization launched in 1999 is a momentum for local governments to improve the quality of the region through increased development outcomes and empower local governments in the formulation of economic and political decisions. Because those who know the condition of each environment are the each regional governments. Regional desentralization provides full authority to local governments to manage local resources in order to improve the welfare conditions of local communities.

Region has a chance to become policy makers to increase social welfare. Faced with the challenges of regional development disparities between regencies/cities. The most frequently highlighted gap is the regional income gap. The income gap is often measured using the Gini index. In this study, the determination of regional income

* Corresponding author: firmansyah@live.undip.ac.id 
distribution index or public facilities area using gini index. Gini index is basically an index that describes lame or not distribution of regional income or public facilities in a country.

Inequality in distribution of income that occurred was allegedly affected by the inequality distribution of public facilities. Basically, public facilities are facilities provided by the state to be utilized by the people. But in its development, public facilities are not only provided by the government but also provided by the private sector. Public facilities that are often utilized by the general public are education facilities, health facilities, telecommunication facilities, and transportation facilities.

\section{Methodology}

The data used in this study comes from secondary data drawn from statistics published by the Central Bureau of Central Java Province[3]. Time series data the period 1999 to 2013 was used to predict the effect of gaps educational, health, and road conditions regencies/cities on income distribution inequality in Central Java.

\section{Discussion}

Multiple regression models are used in estimation. In this study, the distribution of income in Central Java province is estimated to be affected by the distribution of public facilities. Thus we can draw an estimation model as follows :

Where :

$\mathrm{G}_{\mathrm{Y}} \quad=$ Gini Index of Income

$\mathrm{G}_{\mathrm{SD}}=$ Gini Index of Elementary School Facilities

$\mathrm{G}_{\mathrm{SMP}}=$ Gini Index of Junior High School

$\mathrm{G}_{\mathrm{SMU}}=$ Gini Index of High School Facilities

$\mathrm{G}_{\mathrm{RS}} \quad=$ Gini Index of Hospital

$\mathrm{G}_{\mathrm{Pk}}=$ Gini Index of Puskesmas

$\mathrm{G}_{\text {Jlnrus }}=$ Gini Index of Street in Heavy Damage Condition

An educational facility infrastructure to support increased welfare through the provision of primary school (X1), secondary school (X2) and high schools (X3). Gaps availability of educational facilities become contributor to inequality of income distribution. H1: the availability of basic school facilities affect income distribution gap; H2: the availability of secondary school facilities affect income distribution gap; H3: availability high school facilities affect income distribution gap.

A health facility infrastructure to support increased welfare through the provision of hospital (X4) and Puskesmas (X5). Gaps availability of health facilities contributed the income distribution gap. H4: availability of hospital facilities affect income distribution gap; $H$ 5: the availability of facilities for health centers affect income distribution gap.

The quality of the road infrastructure to support increased welfare through the worthiness of road conditions. Damaged road conditions (X6) become a contributor to the income distribution gap. H 6: damaged road conditions affect income distribution gap.

Dependent Variable: LOGY

\begin{tabular}{|c|c|c|c|c|}
\hline Variable & Coefficient & Std. Error & t-Statistic & Prob. \\
\hline $\mathrm{C}$ & -0.980105 & 0.267082 & -3.669671 & 0.0063 \\
\hline LOGSD & 0.008621 & 0.370460 & 0.023271 & 0.9820 \\
\hline LOGSMP & 0.174136 & 0.167178 & 1.041621 & 0.3280 \\
\hline LOGSMA & -0.927784 & 0.137260 & -6.759337 & 0.0001 \\
\hline LOGRS & -0.208600 & 0.043926 & -4.748892 & 0.0014 \\
\hline LOGPUS & -0.073182 & 0.104759 & -0.698575 & 0.5046 \\
\hline LOGJLNRUS & 0.692463 & 0.270504 & 2.559901 & 0.0337 \\
\hline R-squared & 0.984524 & \multicolumn{3}{|c|}{ Mean dependent var -0.507687} \\
\hline $\begin{array}{l}\text { Adjusted R- } \\
\text { squared }\end{array}$ & 0072017 & \multirow{2}{*}{\multicolumn{2}{|c|}{$\begin{array}{l}\text { S.D. dependent var } \\
\text { Akaike info }\end{array}$}} & \\
\hline $\begin{array}{l}\text { squared } \\
\text { S.E. of }\end{array}$ & \multirow{2}{*}{\multicolumn{3}{|c|}{$\begin{array}{l}\text { Akaike info } \\
0.009453 \text { criterion }\end{array}$}} & 0.057438 \\
\hline regression & & & & -6.180339 \\
\hline $\begin{array}{l}\text { Sum squared } \\
\text { resid }\end{array}$ & 0.000715 & \multicolumn{2}{|c|}{$\begin{array}{l}\text { Schwarz criterion } \\
\text { Hannan-Quinn }\end{array}$} & -5.849915 \\
\hline Log likelihood & \multicolumn{3}{|c|}{53.35254 criter. } & -6.183858 \\
\hline F-statistic & 84.82074 & \multirow{2}{*}{\multicolumn{2}{|c|}{ Durbin-Watson stat }} & 2.583707 \\
\hline Prob(F-statistic) & 0.000001 & & & \\
\hline
\end{tabular}

Results of regression estimation using Eviews 9 shows the regression equation as follows:

$\log Y=-0.9801+0.0086 \log D D+0.1741 \log S M P-0.9278 \log S M A-0.2086 \operatorname{LogRS}$ $-0.0732 \log P u s+0.6925 \log \mid \ln R u s$

Based on the estimates result above, some interpretation can be arranged as follows:

a. LogSD probability of 0.982 showed that no effect inequality of availability elementary school facility on the unequal distribution of income, so that $\mathrm{H} 1$ is rejected.

b. LogSMP probability of 0.328 show that no influence inequality secondary school facilities on the unequal distribution of income, so that $\mathrm{H} 2$ was rejected.

c. LogSMA probability of 0.0001 indicates an inequality in the availability of high school facilities influence on the inequality of income distribution, so that $\mathrm{H} 3$ is accepted.

d. LogRS probability of 0.0014 shows the influence of inequality availability of hospital on unequal distribution of income, so that $\mathrm{H} 4$ is accepted.

e. LogPus probability of 0.5046 showed no effect of inequality availability of facilities for health centers on the unequal distribution of income, so that H5 was rejected.

f. LogJlnRus probability of 0.0337 shows the influence damaged road conditions on the unequal distribution of income, so that $\mathrm{H} 6$ received.

\section{Conclusion}

Inequality of income distribution is affected by the inequality distribution of public facilities. Rationally, 
the increase in income will be greatly influenced by the provision of public facilities by the government and the private sector. In reality, income distribution in Central Java is affected by inequalities in the distribution of school infrastructure, health infrastructure, environment and transportation infrastructure. The uneven distribution of hospitals causes the condition of public health to decline.

On the other hand, the existence of imbalance in transportation infrastructure condition resulted in the business and trade process being disturbed, because the community is unable to access the communication more quickly. And the existence of road damage will result in the distribution of capital and labor mobility will be disrupted.

The meaning of the existence of development for the community, influenced by the provision of public facilities by the government. The more equitable and quality service provided by the government, the more meaningful the government's performance for the community4 importantly in regional development are multidimensional actions to empower people, as proposed by Thomas et al.2 as follows:
1. Enhance the assets of the poor by ensuring access to quality health and education services.

2. Increase attention to distributive effects and public investment and reduce subsidies to the types of educational and health services that benefit the rich.

3. Facilitate the full use of human capital by empowering the poor with opportunities for land, credit, training and employment.

4. Complete all human capital investments with economic reform and market openness, which increases educational productivity.

\section{References}

1. M. P. Todaro \& S. C. Smith. "Economic Development", 11th Edition, Prentice Hall (2011).

2. Thomas, et.al. "The Quality of Growth", alih bahasa oleh Marcus Prihminto Widodo, Gramedia, Jakarta (2000).

3. The Central Bureau of Statistics Central Java Province several years.

4. R. A. Mallarangeng et.al, "Otonomi Daerah : Perspektif Teoritis dan Praktis", Bigraf Publising, Yogyakarta (2001). 